\title{
ANALISIS RISIKO KESELAMATAN DAN KESEHATAN KERJA MANUFAKTUR PADA PROSES PEMBUATAN SUKU CADANG MOBIL ARM VISOR SHAFT
}

\author{
Endah Asti Budianti ${ }^{1}$, Reda Rizal2) \\ 1) Mahasiswi Prodi Kesmas NRP. 1110713033. email : budianti.29@gmail.com \\ 2) Pembimbing NIP. 1959.0825.1988.0310.01. email : reda_rizal59@yahoo.co.id
}

\begin{abstract}
PT. $X Y Z$ is a manufacture company of vehicle spare parts. One of the product is Arm Visor Shaft D01N. The process of making Arm Visor Shaft D01N can be exposed to be potential risk for workers. The source of potential risk is from the material, equipment, machine, environment and the other hazards. Therefore the risk management of occupational health and safety is very important to be implemented in the company. Hazard identification method using the Job Safety Analysis (JSA), while for risk analysis is undertaken by semi-quantitative method that uses risk assessment criteria (consequence, probability and exposure). Based on the research that the level of risk in the process of making Arm Visor Shaft are risk with very high level has 8, substantial level has 23, priority 2 level has 2 and acceptable level has 3.
\end{abstract}

Keywords : semi-quantitative risk analysis, risk, safety, health.

\section{PENDAHULUAN}

Era globalisasi dapat memberikan dampak negatif terhadap tatanan lingkungan kehidupan global, termasuk dunia usaha yang diwarnai dengan ketatnya persaingan yang tidak hanya menekankan pada faktor-faktor kualitas dan kuantitas hasil produk manufaktur, namun juga kepatuhan terhadap standar keselamatan dan kesehatan kerja. Masalah utama yang selalu muncul pada setiap kegiatan kerja manufaktur adalah timbulnya ancaman keselamatan dan kesehatan kerja.

Salah satu ancaman keselamatan kerja di lingkungan kerja manufaktur adalah masalah kecelakaan kerja yang dapat terjadi oleh berbagai factor, misalnya karena factor kondisi alat dan peralatan kerja ataupun faktor kualitas material bahan baku yang kurang baik dan mengandung unsur bahaya. Kecelakaan kerja dapat pula dipicu oleh kondisi lingkungan kerja yang tidak nyaman seperti kondisi ventilasi yang kurang baik, kurang penerangan, bising, atau suhu lingkungan ruang kerja yang melampaui nilai ambang batas aman. Disamping itu, kecelakaan kerja dapat terjadi bersumber dari perilaku manusia (pekerja) yang melakukan pekerjaan secara tidak aman atau unsafe action.

Berdasarkan data dari PT. Jamsostek (Persero) menunjukkan angka kecelakaan kerja cenderung naik setiap tahunnya, dimana pada tahun 2012 terjadi 103.704 kasus kecelakaan kerja, dimana 91,21\% korban kecelakaan dapat sembuh dan kembali bekerja, 3,8\% mengalami cacat fungsi, $2,61 \%$ mengalami cacat sebagian, cacat total (37 kasus) dan sisanya meninggal dunia (2.419 kasus). Angka kecelakaan kerja tersebut mengalami kenaikan di bandingkan 5 tahun sebelumnya, dimana pada tahun 2011terjadi 99.491 kasus atau ratarata 414 kasus kecelakaan kerja per hari, pada tahun 2010 terjadi 98.711 kasus kecelakaan kerja,tahun 2009 (96.314 kasus), tahun 2008 terjadi 94.736 kasus dan tahun 2007 terjadi 83.714 kasus. (Erphandi, 2012, hlm.15).

Bahaya dan risiko keselamatan dan kesehatan kerja tidak dapat dihindari dalam setiap pekerjaan. Oleh karena itu, diperlukan upaya pengendalian demi mengurangi kerugian (loss) yang akan terjadi akibat dari bahaya dan risiko tersebut. Salah satu upaya pengendalian yang dapat dilakukan adalah melakukan manajemen risiko. Sasaran utama manajemen risiko adalah mengelola risiko untuk mencegah terjadinya kecelakaan atau kejadian yang tidak diinginkan.

PT. XYZ adalah perusahaan manufaktur yang bergerak di bidang pembuatan suku cadang kendaraan bermotor (mobil). Salah satu produk 
yang dihasilkan PT. XYZ adalah Arm Visor Shaft D01N, dimana proses pembuatan produk ini melibatkan banyak pekerja yang langsung berhadapan dengan potensi risiko yang berasal dari mesin mekanik, panas, getaran, peralatan dan bahaya lainnya. Berdasarkan data kecelakaan kerja yang dimiliki PT. XYZ, telah terjadi kenaikan angka kecelakaan kerja dalam dua tahun terakhir. Dimana terjadi 2 kasus kecelakaan kerja pada tahun 2013 dan terjadi 3 kasus kecelakaan kerja pada tahun 2014. Memperhatikan angka kecelakaan kerja tersebut di atas maka penerapan manajemen risiko sangat penting diterapkan di lingkungan PT. XYZ.

\section{TINJAUAN TEORI}

Terminologi keselamatan dan kesehatan kerja menurut Keputusan Menteri Tenaga Kerja R.I No. Kep. 463/MEN/1993 adalah upaya perlindungan yang ditujukan agar tenaga kerja dan orang laainnya di tempat kerja/perusahaan selalu dalam keadaan selamat dan sehat, serta agar setiap sumber produksi dapat digunakan secara aman dan efisien.

Keselamatan kerja dalam suatu tempat kerja mencakup berbagai aspek yang berkaitan dengan kondisi dan cara kerja. Persyaratan keselamatan kerja menurut Undang-undang No. 1 tahun 1970 adalah sebagai berikut:

1 Mencegah dan mengurangi kecelakaan. Hal ini berkaitan dengan upaya pencegahan kecelakaan dari setiap pekerjaan atau kegiatan berbahaya

2. Mencegah, mengurangi bahaya kebakaran dan memadamkan kebakaran. Hal ini berkaitan dengan sistem proteksi kebakaran (fire protec-tion system) dan pencegahan bahaya kebakaran (fire prevention)

3. Memberi kesempatan atau jalan menyelamatkan diri dalam kejadian kebakaran atau kejadian lainnya. Hal ini berkaitan dengan sistem tanggap darurat (emergency response) serta fasilitas penyelamat di dalam bangunan atau tempat kerja (means of escape)

4. Memberikan pertolongan dalam kecelakaan. Hal ini menyangkut aspek $\mathrm{P} 3 \mathrm{~K}$ atau pertolongan jika terjadi kecelakaan termasuk resque dan pertolongan korban

5. Memberikan alat pelindung diri bagi pekerja. Hal ini berkaitan dengan penyediaan alat keselamatan yang sesuai (Alat Pelindung Diri) untuk setiap pekerjaan yang berbahaya. 6. Mencegah dan mengendalikan timbul atau menyebar luasnya suhu, kelembapan, debu, kotoran, asap, uap, gas, hembusan, angin, cuaca, sinar, atau radiasi, suara atau getaran. Hal ini berkaitan dengan keselamatan lingkungan kerja, pencemaran atau buangan industri serta kesehatan kerja

7. Mencegah dan mengendalikan timbulnya penya kit akibat kerja baik fisik,maupun psikis,peracunan, infeksi dan penularan. Hal ini berkaitan dengan aspek kesehatan kerja dan higiene industri.

8. Memperoleh penerangan yang cukup dan sesuai. 9. Menyelenggarakan penyegaran udara yang baik. 10.Memlihara kebersihan, kesehatan danketertiban. 11.Memperoleh kesesrasian antar tenaga kerja, alat kerja, lingkungan, cara dan proses kerja. 12.Mengamankan dan memperlancar pengangkutan orang, binatang, tanaman, atau barang. 13. Mencegah terkena aliran listrik yang berbahaya.

Keselamatan dan kesehatan kerja merupakan hal yang penting bagi perusahaan, karena dampak kecelakaan dan penyakit akibat kerja tidak hanya merugikan karyawan, tetapi juga perusahaan baik secara langsung maupun tidak langsung.

Keterlibatan secara aktif dari manajemen perusahaan sangat penting agar terciptanya kondisi tempat kerja yang aman.

Kecelakaan kerja menurut Peraturan Menteri Tenaga Kerja (Permenaker) Nomor: 03/Men/1998 adalah suatu kejadian yang tidak dikehendaki dan tidak diduga semula yang dapat menimbulkan korban jiwa dan kerusakan harta benda. Sedangkan menurut Peraturan Menteri Tenaga Kerja Nomor 03/Men/1994 tentang Jamsostek, menyebutkan bahwa kecelakaan kerja adalah kecelakaan berhubungan dengan hubungan kerja, termasuk penyakit yang timbul karena hubungan kerja, termasuk penyakit yang timbul karena hubungan kerja demikian pula kecelakaan yang terjadi dalam perjalanan berangkat dari rumah menuju tempat kerja dan pulang ke rumah melalui jalan biasa atau wajar dilalui.

Menurut Frank E. Bird Jr dalam Ramli (2010:31); kecelakaan adalah suatu kejadian yang tidak dikehendaki, dapat mengakibatkan kerugian jiwa serta kerusakan harta benda dan biasanya terjadi sebagai akibat dari adanya kontak dengan sumber yang melebihi ambang batas atau struktur. Menurut H.W Heinrich dalam Ramli (2010); bahwa penyebab kecelakaan kerja terbagi menjadi dua yaitu: 
1. Unsafe action (tindakan tidak aman). Unsafe action adalah suatu tindakan yang memicu terjadinya suatu kecelakaan kerja. Contoh merokok di tempat rawan terjadi kebakaran, tidak mematuhi peraturan dan larangan K3.

2. Unsafe condition (kondisi tidak aman). Unsafe condition berkaitan erat dengan kondisi lingkungan kerja baik alat, material atau lingkungan yang tidak aman. Sebagai contoh lantai yang licin, tangga yang rusak,pencahayaan yang kurang atau kebisingan yang melampaui NAB (Nilai Ambang Batas).

Organisasi Perburuhan International (ILO), kecelakaan akibat kerja diklasifikasikan berdasarkan empat macam penggolongan, yaitu:

1. Klasifikasi Menurut Jenis Kecelakaan

a. Terjatuh

b. Tertimpa benda

c. Tertumbuk atau terkena benda-benda

d. Terjepit oleh benda

e. Gerakan-gerakan melebihi kemampuan

f. Pengaruh suhu tinggi

g. Terkena aliran listrik

h. Kontak bahaya bahan-bahan berbahaya atau radiasi

2. Klasifikasi Menurut Penyebab

a. Mesin, misalnya: mesin pembangkit tenaga listrik, mesin penggergajian kayu dan sebagainya

b. Alat angkut, misalnya: alat angkut darat, udara dan alat angkut air

c. Peralatan lain, misalnya: dapur pembakar dan pemanas, instalasi pendingin, alat-alat listrik, dan sebagainya

d. Bahan-bahan, zat-zat, dan radiasi, misalnya: bahan peledak, gas, zat-zat kimia, dan sebagainya

e. Lingkungan kerja (Di luar bangunan, di dalam bangunan dan dibawah tanah)

f. Dan penyebab lainnya

3. Klasifikasi menurut Luka atau Kelainan
a. Patah tulang
b. Dislokasi (keseleo)
c. Renggang otot (Urat)
d. Memar dan luka dalam yang lain
e. Amputasi luka dipermukaan
f. Geger dan memar
g. Luka bakar
h. Keracunan mendadak
i. Pengaruh radiasi

4. Klasifikasi Menurut Letak Kelainan atau Luka di Tubuh

a. Kepala

b. Leher

c. Badan

d. Anggota atas

e. Anggota bawah

f. Tempat lain yang tidak termasuk klasifikasi tersebut.

Bahaya adalah suatu potensi kerugian atau situasi dengan potensi yang menyebabkan kerugian. Bahaya mempunyai arti sumber potensi kerusakan maupun situasi yang berpotensi menyebabkan kerugian. Bahaya merupakan sumber risiko apabila risiko tersebut diartikan sebagai sesuatu yang negative (Ramli, 2010, hlm.57).

OHSAS 18001 (2007); bahaya adalah sumber, situasi atau tindakan yang potensi mencederai pekerja atau menimbulkan penyakit atau kombinasi dari keduanya. Sedangkan definisi bahaya menurut Health and Safety Comission (1992), bahaya adalah sesuatu yang memiliki potensi untuk menyebabkan kerugian atau kerusakan. Bentuk dari bhaya dapat berasal dari mesin kerja, bahan baku, metode kerja, serta hal-hal yang dapat menimbulkan risiko besar dan penting meskipun potensi bahanya sangat kecil dengan pengendalian yang tepat dan benar, risiko dapat direduksi sehingga bahaya yang lebih besar lagi dapat direduksi pula.

Dalam terminology keselamatan dan kesehatan kerja (K3), bahaya diklasifikasikan menjadi 2 (dua), yaitu :

1. Bahaya Keselamatan Kerja (Safety Hazard). Hal ini merupakan jenis bahaya yang berdampak pada timbulnya kecelakaan yang dapat menyebabkan luka (injury) hingga kematian, serta kerusakan property perusahaan.Dampaknya bersifat akut.Jenis bahaya keselamatan antara lain:

a. Bahaya Mekanik, disebabkan oleh mesin atau alat kerja mekanik seperti tersayat, terjatuh, tertindih dan terpeleset.

b. Bahaya Elektrik, disebabkan peralatan yang mengandung arus listrik

c. Bahaya Kebakaran, disebabkan oleh substansi kimia yang bersifat flammable (udah terbakar)

d. Bahaya Peledakan, disebabkan oleh substansi kimia yang sifatknya explosive.

2. Bahaya Kesehatan Kerja (Health Hazard). Hal ini merupakan jenis bahya yang berdampak pada kesehatan, menyebabkan gangguan 
kesehatan dan penyakit akibat kerja. Dampaknya bersifat kronis. Jenis bahaya kesehatan antara lain:

a. Bahaya Fisik, antara lain kebisigan, getaran, radiasi, ion dan non pengion, suhu ekstrim dan pencahayaan

b. Bahaya Kimia, antara lain yang berkaitan dengan material atau bahan seperti antiseptik, aerosol, insektisida, dust, gas.

c. Bahaya Biologi,antara lain berkaitan dengan mahluk hidup yang berada di lingkungan kerja yaitu bakteri, virus, protozoa dan fungi (jamur) yang bersifat patogen.

d. Bahaya Ergonomi, antara lain repretative movement (gerakan berulang), statistic posture, manual handling dan postur janggal.

e. Bahaya Psikologi, antara lain beban kerja yangterlalu berat, hubungan dan kondisi kerja yang tidak nyaman.

\section{METODE PENELITIAN}

Penelitian ini dapat dikategorikan sebagai penelitian survai dan pengamatan lapangan di lingkungan kerja manufaktur. Data yang diperoleh dianalisis menggunakan standar manajemen risiko AS/NZS 4360:2004, sehingga hasil penelitian ini dapat digolongkan dalam penelitian yang bersifat deskriptif
Penelitian ini menggunakan tools berupa standar manajemen risiko AS/NZS 4360:2004 dan perhitungan risiko dengan menggunakan formula W.T Fine. Kegiatan penelitian ini juga menggunakan kuesioner untuk menhimpun data dan informasi tentang kondisi pekerja dan persepsi pekerja tentang keselamatan dan kesehatan kerja di lingkungan kerja manufaktur.

Tahapan penelitian ini adalah melakukan identifikasi bahaya kerja dan risiko keselamatan dan kesehatan kerja pada proses pembuatan Arm Visor Shaft D01N menggunakan tools Job Safety Analysis (JSA), kemudian melakukan analisis terhadap risiko yang telah diidentifikasi dengan menentukan besar nilai probability, exposure dan consequence. Selanjutnya melakukan penghitungan terhadap besarnya nilai risiko kecelakaan kerja menggunakan rumus W.T Fine yaitu Consequence * Exposure * Probability dan membandingkannya dengan nilai risiko kerja yang terdapat tabel klasifikasi risiko kerja.

\section{HASIL DAN ANALISIS}

PT. XYZ adalah perusahaan manufaktur yang bergerak di bidang pembuatan sparepart mobil, salah satu produk yang dihasilkan dan menjadi obyek penelitian ini adalah produk Arm Visor Shaft D01N. Pembuatan produk ini

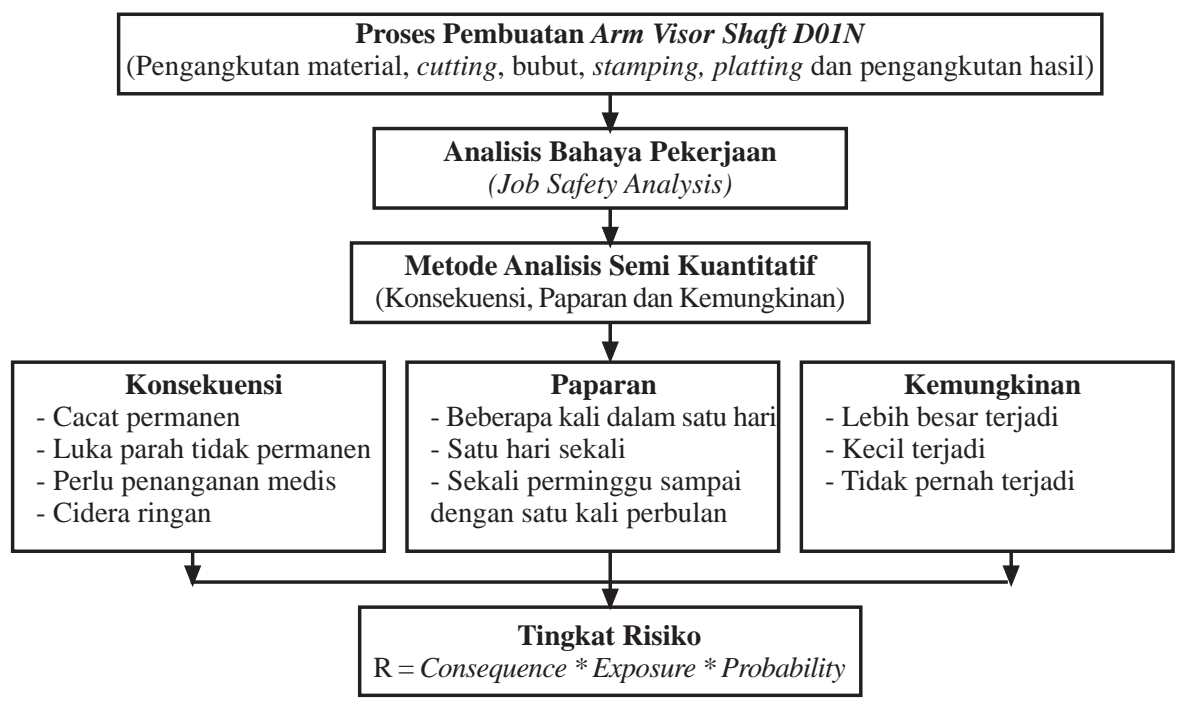

Gambar 1. Kerangka Konsep Penelitian

menggunakan bahan material As. Terdapat 6 tahap proses pembuatan produk Arm Visor Shaft D01N yaitu pengangkutan material ke gudang penyimpanan, proses cutting, proses bubut, proses stamping, proses platting dan pengangkutan hasil. Identifikasi bahaya pada proses pembuatan produk Arm Visor
Shaft D01N menggunakan Job Safety Analysis. Setelah dilakukan proses identfikasi bahaya kerja, maka selanjutnya dilakukan analisis risiko dengan menggunakan metode semi kuantitatif dengan menghitung nilai risiko yang akan diperoleh dari estimasi consequence, exposure dan probability. 
Tabel 1. Analisis Risiko Proses Pembuatan Arm Visor Shaft D01N

\begin{tabular}{|c|c|c|c|c|c|c|c|c|}
\hline \multirow{2}{*}{ No. } & \multirow{2}{*}{$\begin{array}{l}\text { Tahapan } \\
\text { Pekerjaan }\end{array}$} & \multirow{2}{*}{ Risiko } & \multirow{2}{*}{ Dampak } & \multicolumn{3}{|c|}{ Analisis risiko } & \multirow{2}{*}{$\begin{array}{c}\begin{array}{c}\text { Nilai } \\
\text { Risiko }\end{array} \\
C^{*} E^{*} P\end{array}$} & \multirow{2}{*}{$\begin{array}{l}\text { Tingkat } \\
\text { Risiko }\end{array}$} \\
\hline & & & & $\mathrm{C}$ & $\mathrm{E}$ & $\mathrm{P}$ & & \\
\hline \multirow[t]{5}{*}{1.} & \multirow[t]{2}{*}{$\begin{array}{l}\text { Pengangkutan } \\
\text { material as }\end{array}$} & $\begin{array}{l}\text { 1. Tergores besi } \\
\text { Tangan pekerja dapat } \\
\text { tergores material as } \\
\text { karena permukaan besi } \\
\text { yang tajam. }\end{array}$ & Luka ringan & 1 & 3 & 3 & 9 & Acceptable \\
\hline & & $\begin{array}{ll}\text { 2. } & \text { Kaki terluka } \\
\text { Pekerja dapat } \\
\text { mengalami luka apabila } \\
\text { material as yang } \\
\text { diangkut terjatuh } \\
\text { mengenai kaki pekerja } \\
\end{array}$ & $\begin{array}{l}\text { Luka yang } \\
\text { membutuhkan } \\
\text { penanganan } \\
\text { medis }\end{array}$ & 5 & 3 & 3 & 45 & Priority 2 \\
\hline & & $\begin{array}{l}\text { pada saat proses } \\
\text { pengangkutan }\end{array}$ & & & & & & \\
\hline & & $\begin{array}{l}\text { 3. Terpeleset } \\
\text { Apabila tidak berhati- } \\
\text { hati pekerja dapat } \\
\text { terpeleset dikarnakan } \\
\text { jalan yang licin }\end{array}$ & Luka serius & 15 & 3 & 1 & 45 & Priority 2 \\
\hline & & $\begin{array}{l}\text { 4. Melukai pekerja lain } \\
\text { Pekerja lain dapat } \\
\text { terluka dikarenakan } \\
\text { tidak ada jalur khusus } \\
\text { untuk mengangkut } \\
\text { material menuju ke } \\
\text { gudang penyimpanan. } \\
\end{array}$ & Luka serius & 15 & 3 & 3 & 135 & Subtansial \\
\hline \multirow[t]{3}{*}{2.} & \multirow[t]{3}{*}{ Proses cutting } & $\begin{array}{l}\text { 1. Jari terpotong } \\
\text { Jari pekerja dapat } \\
\text { terpotong mesin cutting } \\
\text { saat memasukan } \\
\text { material as pada mesin } \\
\text { apabila pekerja tidak } \\
\text { berhati-hati. } \\
\end{array}$ & $\begin{array}{l}\text { Cidera } \\
\text { berat } / \text { kecacata } \\
\mathrm{n} \text { permanen }\end{array}$ & 25 & 6 & 3 & 450 & Very high \\
\hline & & $\begin{array}{l}\text { 2. Mata terkena serpihan } \\
\text { material } \\
\text { Mata pekerja dapat } \\
\text { terkana serpihan yang } \\
\text { berasal dari material } \\
\text { saat proses cutting }\end{array}$ & $\begin{array}{l}\text { Mengakibatka } \\
\text { n kerusakan } \\
\text { indera } \\
\text { penglihatan } \\
\text { dengan } \\
\text { paparan } \\
\text { jangka panjang }\end{array}$ & 25 & 6 & 0,5 & 75 & Subtansial \\
\hline & & $\begin{array}{ll}\text { 3. } & \text { Tangan terluka } \\
& \text { Tangan pekerja dapat } \\
\text { terluka pada saat } \\
\text { melakukan proses cutting }\end{array}$ & Luka ringan & 1 & 6 & 3 & 18 & Acceptable \\
\hline \multirow[t]{3}{*}{3.} & $\begin{array}{l}\text { Proses } \\
\text { Pembubutan } \\
\end{array}$ & & & & & & & \\
\hline & \multirow[t]{2}{*}{$\begin{array}{l}\text { Bubut Bagian } \\
\text { Sudut }\end{array}$} & $\begin{array}{l}\text { 1. Tangan terluka } \\
\text { Tangan pekerja dapat } \\
\text { terluka pada mesin, } \\
\text { karna ada bagian mesin } \\
\text { yang tidak tertutup. }\end{array}$ & $\begin{array}{l}\text { Luka yang } \\
\text { harus } \\
\text { mendapatkan } \\
\text { penangan } \\
\text { medis } \\
\end{array}$ & 5 & 10 & 3 & 150 & Subtansial \\
\hline & & $\begin{array}{l}\text { 2. Jari terjepit } \\
\text { Apabila pekerja tidak } \\
\text { berhati-hati saat } \\
\text { melakukan pekerjaan, } \\
\text { tangan pekerja dapat }\end{array}$ & Luka serius & 15 & 10 & 3 & 450 & Very high \\
\hline
\end{tabular}




\begin{tabular}{|c|c|c|c|c|c|c|c|}
\hline & $\begin{array}{l}\text { 3. Terhirup fume } \\
\text { Pekerja dapat terhirup } \\
\text { fume yang berasal dari } \\
\text { mesin. }\end{array}$ & $\begin{array}{l}\text { Mengakibatka } \\
\mathrm{n} \text { kerusakan } \\
\text { organ tubuh } \\
\text { dengan } \\
\text { paparan } \\
\text { jangka } \\
\text { panjang }\end{array}$ & 25 & 10 & 0,5 & 125 & Subtansial \\
\hline & $\begin{array}{l}\text { 4. Mata terkena serpihan } \\
\text { part } \\
\text { Serpihan part pada } \\
\text { proses sayat dapat } \\
\text { masuk ke mata pekerja. }\end{array}$ & $\begin{array}{l}\text { Mengakibatka } \\
\mathrm{n} \text { kerusakan } \\
\text { indera } \\
\text { penglihatan } \\
\text { dengan } \\
\text { paparan } \\
\text { jangka } \\
\text { panjang }\end{array}$ & 25 & 10 & 0,5 & 125 & Subtansial \\
\hline & $\begin{array}{ll}\text { 5. } & \text { Terhirup serpihan part } \\
\text { Pekerja dapat terhirup } \\
\text { serpihan part saat } \\
\text { melakukan proses sayat. }\end{array}$ & $\begin{array}{l}\text { Mengakibatka } \\
\mathrm{n} \text { kerusakan } \\
\text { organ tubuh } \\
\text { dengan } \\
\text { paparan } \\
\text { jangka } \\
\text { panjang }\end{array}$ & 25 & 10 & 0,5 & 125 & Subtansial \\
\hline & $\begin{array}{ll}\text { 6. } & \text { Terpeleset } \\
\text { 7. } & \text { Pekerja dapat terpeleset } \\
\text { dikarenakan lantai yang } \\
\text { licin dan disebabkan } \\
\text { banyaknya part yang } \\
\text { berserakan di lantai }\end{array}$ & Luka serius & 15 & 10 & 0,5 & 75 & Substansial \\
\hline $\begin{array}{l}\text { Bubut Proses } \\
\text { Sayat dan } \\
\text { Taper }\end{array}$ & $\begin{array}{ll}\text { 8. } & \text { Terhirup fume } \\
\text { Pekerja dapat terhirup } \\
\text { fume yang berasal dari } \\
\text { mesin. }\end{array}$ & $\begin{array}{l}\text { Mengakibatka } \\
\mathrm{n} \text { kerusakan } \\
\text { organ tubuh } \\
\text { dengan } \\
\text { paparan } \\
\text { jangka } \\
\text { panjang }\end{array}$ & 25 & 10 & 0,5 & 125 & Subtansial \\
\hline & $\begin{array}{l}\text { 9. Tangan terluka } \\
\text { Tangan pekerja dapat } \\
\text { terluka pada mesin, } \\
\text { karna ada bagian mesin } \\
\text { yang tidak tertutup. } \\
\end{array}$ & $\begin{array}{l}\text { luka yang } \\
\text { membutuhkan } \\
\text { penanganan } \\
\text { medis }\end{array}$ & 5 & 10 & 3 & 150 & Subtansial \\
\hline & $\begin{array}{l}\text { 10. Terpeleset } \\
\text { Pekerja dapat terpeleset } \\
\text { dikarenakan lantai yang } \\
\text { licin dan disebabkan } \\
\text { banyaknya part yang } \\
\text { berserakan di lantai }\end{array}$ & Luka serius & 15 & 10 & 0,5 & 75 & Substansial \\
\hline & $\begin{array}{l}\text { 11. Jari terjepit } \\
\text { Jari pekerja dapat } \\
\text { terjepit pada mesin } \\
\text { bubut pada saat } \\
\text { memasukaan part atau } \\
\text { menarik part dari mesin }\end{array}$ & Luka serius & 15 & 10 & 3 & 450 & Very high \\
\hline & $\begin{array}{l}\text { 12. Mata terkena serpihan } \\
\text { part } \\
\text { Serpihan part pada } \\
\text { proses sayat dapat } \\
\text { masuk ke mata pekerja. }\end{array}$ & $\begin{array}{l}\text { Mengakibatka } \\
\text { n kerusakan } \\
\text { indera } \\
\text { penglihatan } \\
\text { dengan } \\
\text { paparan } \\
\text { jangka } \\
\text { panjang }\end{array}$ & 25 & 10 & 0,5 & 125 & Subtansial \\
\hline & $\begin{array}{l}\text { 13. Terhirup serpihan part } \\
\text { Pekerja dapat terhirup } \\
\text { serpihan part saat } \\
\text { melakukan proses sayat. }\end{array}$ & $\begin{array}{l}\text { Mengakibatka } \\
\mathrm{n} \text { kerusakan } \\
\text { organ tubuh } \\
\text { dengan } \\
\text { paparan } \\
\text { jangka } \\
\text { panjang }\end{array}$ & 25 & 10 & 0,5 & 125 & Subtansial \\
\hline
\end{tabular}




\begin{tabular}{|c|c|c|c|c|c|c|c|c|}
\hline & \multirow[t]{5}{*}{$\begin{array}{l}\text { Proses } \\
\text { Snay/Ulir }\end{array}$} & $\begin{array}{l}\text { 14. Terpeleset } \\
\text { Pekerja dapat terpeleset } \\
\text { dikarenakan lantai yang } \\
\text { licin dan disebabkan } \\
\text { banyaknya part yang } \\
\text { berserakan di lantai }\end{array}$ & Luka serius & 15 & 10 & 0,5 & 75 & Subtansial \\
\hline & & $\begin{array}{l}\text { 15. Terhirup serpihan part } \\
\text { Pekerja dapat terhirup } \\
\text { serpihan part saat } \\
\text { melakukan proses } \\
\text { snay/ulir. }\end{array}$ & $\begin{array}{l}\text { Mengakibatka } \\
\mathrm{n} \text { kerusakan } \\
\text { organ tubuh } \\
\text { dengan } \\
\text { paparan } \\
\text { jangka } \\
\text { panjang } \\
\end{array}$ & 25 & 10 & 0,5 & 125 & Subtansial \\
\hline & & $\begin{array}{l}\text { 16. Mata terkena serpihan } \\
\text { part } \\
\text { Serpihan part pada } \\
\text { proses sayat dapat } \\
\text { masuk ke mata pekerja. }\end{array}$ & $\begin{array}{l}\text { Mengakibatka } \\
\text { n kerusakan } \\
\text { indera } \\
\text { penglihatan } \\
\text { dengan } \\
\text { paparan } \\
\text { jangka } \\
\text { panjang } \\
\end{array}$ & 25 & 10 & 0,5 & 125 & Subtansial \\
\hline & & $\begin{array}{l}\text { 17. Jari terjepit } \\
\text { Jari pekerja dapat } \\
\text { terjepit pada mesin } \\
\text { bubut pada saat } \\
\text { memasukaan part atau } \\
\text { menarik part dari mesin } \\
\end{array}$ & Luka serius & 15 & 10 & 3 & 450 & Very high \\
\hline & & $\begin{array}{l}\text { 18. Terhirup fume } \\
\text { Pekerja dapat terhirup } \\
\text { fume yang berasal dari } \\
\text { mesin. }\end{array}$ & $\begin{array}{l}\text { Mengakibatka } \\
\mathrm{n} \text { kerusakan } \\
\text { organ tubuh } \\
\text { dengan } \\
\text { paparan } \\
\text { jangka } \\
\text { panjang } \\
\end{array}$ & 25 & 10 & 0,5 & 125 & Subtansial \\
\hline 4. & $\begin{array}{l}\text { Proses } \\
\text { Stamping } \\
\end{array}$ & & & & & & & \\
\hline & $\begin{array}{l}\text { Proses } \\
\text { bending }\end{array}$ & $\begin{array}{l}\text { Jari terjepit } \\
\text { Jari pekerja dapat } \\
\text { terjepit pada mesin } \\
\text { press ketika } \\
\text { memasukan atau } \\
\text { mengeluarkan part saat } \\
\text { proses bending } \\
\end{array}$ & Luka serius & 15 & 10 & 3 & 450 & Very high \\
\hline & & $\begin{array}{l}\text { 2. Mata terkena part } \\
\text { Pada saat proses } \\
\text { pengepressan, part } \\
\text { dapat terpental } \\
\text { mengenai mata pekerja. }\end{array}$ & Luka serius & 15 & 10 & 3 & 450 & Very high \\
\hline & & $\begin{array}{l}\text { 3. Terhirup fume } \\
\text { Pekerja dapat terhirup } \\
\text { fume yang berasal dari } \\
\text { mesin. }\end{array}$ & $\begin{array}{l}\text { Mengakibatka } \\
\mathrm{n} \text { kerusakan } \\
\text { organ tubuh } \\
\text { dengan } \\
\text { paparan } \\
\text { jangka panjang }\end{array}$ & 25 & 10 & 0,5 & 125 & Subtansial \\
\hline & $\begin{array}{l}\text { Proses } \\
\text { Heading }\end{array}$ & $\begin{array}{l}\text { 4. Jari terjepit } \\
\text { Jari pekerja dapat } \\
\text { terjepit pada mesin } \\
\text { press ketika } \\
\text { memasukan atau } \\
\text { mengeluarkan part saat } \\
\text { proses heading }\end{array}$ & Luka serius & 15 & 10 & 3 & 450 & Very High \\
\hline & & $\begin{array}{ll}\text { 5. } & \text { Terhirup fume } \\
\text { Pekerja terhirup fume } \\
\text { yang berasal dari mesin. }\end{array}$ & $\begin{array}{l}\text { Mengakibatka } \\
\mathrm{n} \text { kerusakan } \\
\text { organ tubuh } \\
\text { dengan paparan } \\
\text { jangka panjang } \\
\end{array}$ & 25 & 10 & 0,5 & 150 & Subtansial \\
\hline
\end{tabular}




\begin{tabular}{|c|c|c|c|c|c|c|c|c|}
\hline & \multirow[t]{2}{*}{$\begin{array}{l}\text { Proses } \\
\text { Stopper }\end{array}$} & $\begin{array}{l}\text { 6. Jari terjepit } \\
\text { Jari pekerja dapat } \\
\text { terjepit pada mesin } \\
\text { press ketika } \\
\text { memasukan atau } \\
\text { mengeluarkan part saat } \\
\text { proses stopper }\end{array}$ & Luka serius & 15 & 10 & 3 & 450 & Very high \\
\hline & & $\begin{array}{l}\text { 7. Terhirup fume } \\
\text { Pekerja dapat terhirup } \\
\text { fume yang berasal dari } \\
\text { mesin. }\end{array}$ & $\begin{array}{l}\text { Mengakibatka } \\
\mathrm{n} \text { kerusakan } \\
\text { organ tubuh } \\
\text { dengan } \\
\text { paparan } \\
\text { jangka panjang }\end{array}$ & 25 & 10 & 0,5 & 125 & Subtansial \\
\hline \multirow[t]{3}{*}{5.} & \multirow[t]{3}{*}{$\begin{array}{l}\text { Proses } \\
\text { Platting }\end{array}$} & $\begin{array}{ll}\text { 8. } & \text { Terhirup krom } \\
\text { Pada saat melakukan } \\
\text { proses platting, pekerja } \\
\text { dapat terhirup krom }\end{array}$ & $\begin{array}{l}\text { Mengakibatka } \\
\mathrm{n} \text { kerusakan } \\
\text { organ tubuh } \\
\text { dengan } \\
\text { paparan } \\
\text { jangka } \\
\text { panjang }\end{array}$ & 25 & 6 & 0,5 & 75 & Subtansial \\
\hline & & $\begin{array}{l}\text { 9. Mata terkena uap krom } \\
\text { Mata pekerja akan } \\
\text { terkena uap chrome } \\
\text { pada saat proses } \\
\text { platting }\end{array}$ & $\begin{array}{l}\text { Mengakibatka } \\
\mathrm{n} \text { kerusakan } \\
\text { indera } \\
\text { penglihatan } \\
\text { dengan } \\
\text { paparan } \\
\text { jangka } \\
\text { panjang } \\
\end{array}$ & 25 & 6 & 0,5 & 75 & Subtansial \\
\hline & & $\begin{array}{l}\text { 10. Terpeleset } \\
\text { Pekerja dapat terpeleset } \\
\text { pada proses pencucian } \\
\text { part dan pengangkatan } \\
\text { part setelah proses } \\
\text { pencucuian karna lantai } \\
\text { yang licin }\end{array}$ & Luka serius & 15 & 6 & 1 & 90 & Subtansial \\
\hline \multirow[t]{2}{*}{6.} & \multirow{2}{*}{$\begin{array}{l}\text { Pengangkut } \\
\text { an Produk } \\
\text { ke Gudang } \\
\text { Penyimpan } \\
\text { an }\end{array}$} & $\begin{array}{ll}\text { 1. } & \text { Terpeleset. Pekerja } \\
\text { dapat terpeleset karena } \\
\text { kondisi lantai licin. }\end{array}$ & Luka serius & 15 & 6 & 1 & 90 & Subtansial \\
\hline & & $\begin{array}{ll}\text { 2. } & \text { Kaki terluka. Pekerja } \\
\text { dapat mengalami luka } \\
\text { apabila produk yang } \\
\text { diangkut terjatuh } \\
\text { mengenai kaki pekerja } \\
\text { pada saat proses } \\
\text { pengangkutan }\end{array}$ & Luka ringan & 1 & 6 & 1 & 6 & Acceptable \\
\hline
\end{tabular}

\section{KESIMPULAN}

Berdasarkan hasil identifikasi bahaya dan analisis risiko kerja pada pekerja PT. XYZ yang melakukan kegiatan produksi khusus pembuatan produk Arm Visor Shaft D01N, dapat disimpulkan sebagai berikut:

1. Terdapat 6 (enam) tahapan pekerjaan yang dilakukan pekerja pada saat proses pembuatan produk Arm Visor Shaft D01N yaitu:

a. Proses pengangkutan material ke gudang penyimpananan

b. Proses cutting

c. Proses bubut/turet: proses sudut, proses sayat/taper dan proses snay/ulir.

d. Proses stamping: proses bending, proses heading, dan proses stopper.

e. Proses platting.

f. Proses pengangkutan produk ke gudang penyimpanan.

2. Pada proses pembuatan Arm Visor Shaft D01N kemungkinan risiko yang ada adalah tergores besi, kaki terluka, terpeleset, jari terpotong, jari terlilit mesin yang berputar, mata terkena serpihan part atau material, jari terjepit mesin, terhirup fume, terhirup serpihan part, dan terhirup chrome. 
3. Tingkat risiko pada proses pembuatan Arm Visor Shaft D01N yang ditemukan yaitu risiko dengan tingkat risiko very high sebanyak 8 risiko, untuk tingkat risiko subtansial sebanyak 23 risiko, untuk tingkat risiko priority 2 sebanyak 2 (dua) risiko, sedangkan untuk tingkat risiko acceptable sebanyak 3 (tiga) risiko.

\section{SARAN}

Berdasarkan penelitian yang telah dilakukan, saran yang dapat diberikan antara lain: 1. Menerapkan sistem manajemen keselamatan dan kesehatan kerja pada proses produksi.

2. Melakukan perbaikan sistem kerja dengan melakukan rekayasa enggineering, pengendalian administratif, training maupun penggunaan alat pelindung diri yang sesuai dengan jenis pekerjaan.

3. Mengembangkankan Standard Operating Procedure (SOP) tertulis untuk mencegah terjadinya kecelakaan akibat prilaku tidak aman bekerja.

4. Menempatkan safety sign di area kerja, agar pekerja dapat mengetahui dan lebih berhatihati selama bekerja.

5. Melakukan pengawasan terhadap pekerja selama melakukan kegiatan proses dan pengawasan terhadap kepatuhaan penggunaan Alat Pelindung Diri seperti safety goggle, safety shoes, sarung tangan, masker, safety helmet dan cover all.

7. Menegakkan peraturan perusahaan yaitu pemberian sanksi kepada pekerja yang tidak menggunakan Alat Pelindung Diri.

\section{DAFTAR PUSTAKA}

Anonymous. 2004. Standards Australia/Standards

New Zealand Handbook Risk Management Guideline Companion to AS/NZS 4360:2004. Sydney: Standard Australia International Ltd.

Anonymous. 1970. Undang-Undang No. 1 Tahun 1970 tentang Keselamatan Kerja

Anonymous. 1994. Peraturan Menteri Tenaga Kerja Nomor: 03/MEN/1994 tantang Penyelanggaraan Program Jaminan Sosial Tenaga Kerja

Anonymous. 1993. Keputusan Menteri Tenaga
Kerja R.I. No. Kep. 463/MEN/1993 tentang Pedoman Pemberian Penghargaan Keselamatan dan Kesehatan Kerja

Fine, William T. (1971). Mathematical Evaluation for Controlling Hazards. Naval Ordnance Laboratory White OAK : Maryland.

Ramli, S. 2010. Pedoman Praktis Manajemen Risiko dalam Perspektif K3 OHS Risk Management. Jakarta: Dian Rakyat.

Ramli, S. 2010. Sistem Manajemen Keselamatan \& Kesehatan Kerja OHSAS 18001. Jakarta: Dian Rakyat.

Santoso, Haryo, Rani Rumita dan Hutami Nuke Ardani. 2014. Kajian Risiko Kesehatan dan Keselamatan Kerja pada Mill Boiler di Pabrik Gula Pakis Baru Jati. 1st Annual Conference in Industrial and System Engineering, diakses 22 April 2015. http://eprints.undip.ac.id/44484/1/Haryo_ Santoso_PROCEEDING_ACISE_2014_F INAL.pdf

Anonymous. 2015. Profil Perusahaan PT. XYZ, diakses 5 Juni 2015.

http://www.tosamaabadi.com 